\title{
EXPLORING EMPLOYEE ENGAGEMENT: A PROPOSED MODEL OF PREDICTORS AND OUTCOMES
}

\section{RAMINDERPREET KAUR \& DR. GURPREET RANDHAWA}

Senior Research Fellow, University Business School, Guru Nanak Dev University, Amritsar, Punjab, India Associate Professor, University Business School, Guru Nanak Dev University, Amritsar, Punjab, India

\begin{abstract}
The engagement of dedicated workers shaped the success stories of proliferating business organisations. Employees who are very involved in their role in the organization express themselves physically, emotionally and mentally. The research aims to define the possible forecasters of employee engagement, including emotional awareness, supervisor assistance, and working life balance, alongside results such as corporate citizenship, organizational dedication, and company objectives. In this sense, the present study attempts to find out. Also, on the basis of these predictors and outcomes, the study advances a theoretical model. The results of the study have applied implications for HR professionals while formulating and implementing HR policies, strategies and practices for enhancing employee engagement at the workplace.

KEYWORDS: Employee Engagement, Emotional Intelligence, Work Life Balance, Turnover Intentions
\end{abstract}

Received: Jun 08, 2020; Accepted: Jun 28, 2020; Published: Sep 15, 2020; Paper Id.: IJMPERDJUN20201239

\section{INTRODUCTION}

The term 'engagement' refers to the fact of being involved with something. First, Kahn (1990) clarified the idea of employee engagement to "strengthen the role played by organizers; employed and articulated physically, emotionally and cognitively during role performances" in the sense of commitment. Frank et al (2004) accepted this definition of participation as an intellectual and emotional contribution of their employees to their company or the degree of their discretionary engagement. According to resource-based view (RBV), one strategic asset that is hard to emulate in a successful organization is the prevalence of engaged employees and this undoubtedly gives an edge to the organization. Theory of social trade helps to clarify the employee involvement as a clear theoretical context. It states that the parties through a number of interactions, that are in a state of interdependence mutual. A central premise of this theory is that relationships are trust, loyalty \& mutual undertakings over a time whenever the parties adhere to certain reciprocal laws. Through a number of interactions, are in a position of interdependence mutual. A central premise of the theory of relationships are trust, loyalty \& mutual undertakings over a time whenever the parties adhere to certain reciprocal laws. (Cropanzano \& Mitchell, 2005). Thus, employees show their engagement in return for benefits and resources provided by their organization (Saks, 2006). Numerous research studies have shown that there are significant organizational effects in the presence of dedicated employees. The concept of employee engagement has evolved with time owing to certain advantages that accrue to 
the organization. Researchers find, for example, that employee engagement positively affects innovation, showing that efficiency, competitiveness and customer satisfaction are improved (Harter et al., 2002). Positive links between commitment and physical and psychological well-being have also been established (Crabtree, 2005). Studies also revealed that high employee engagement leads to reduced absenteeism (Hewitt, 2013), fewer accidents and lower turnover intentions (Maslach et al., 2001). Researchers have established some employee engagement predictors, including job features, incentives and appreciation, perceived corporate support, and core self-evaluations. While studies have examined different systems in relation to employee participation, other predictors and findings are not very well known, as this formulation is fairly new in the field of organizational behavioural analysis (Saks, 2006). (Ellis \& Sorensen, 2007). Because the dedication of employees is viewed as essential to organizational growth, its main predictors and results should therefore be established and the study is an effort in this direction. The objective of the study is to classify the possible predictors and outcomes of employee involvement. The research also provides a theoretical model that defines employee engagement predictors and outcomes.

\section{Predictors of Employee Engagement (EE)}

Cormier (2010) and Lockwood (2007) claimed that EE does not happen in a void but instead an enabling environment has to be provided by the organizations for employees to stay fully engaged in their jobs. Therefore, EE is foreseen both by the characteristics of the job that the employee performs and the traits of the employee's organization. For the purpose of this study, variables (emotional intelligence, perceived supervisor support and work life balance) have been identified as antecedents of EE. A brief description of these antecedents is as follows:

\section{Emotional Intelligence (EI)}

Salovey \& Mayer (1990) created the EI definition and structured it "as a subset of social intelligentsia that includes the ability to track one's emotions and feelings and to use this knowledge to improve one's thought and behaviour" to differentiate between them. Goleman (2012) later expanded the Salovey and Mayer model that had four EI viz dimensions. Self-consciousness, self-management, social consciousness and management of relationships. Employees with a high level EI are able to handle others and show positive attitudes to colleagues (George, 2000; Randhawa \& Nanda, 2017; Nanda \& Randhawa, 2019). Various research studies (Levitas et al., 2019; Gong et al., 2020) conducted on EI and EE suggested that EI significantly predict EE. Also, Karamustafa \& Kunday (2018) examined 245 professionals from private sector in Turkey and concluded that EI dimensions (relationship management and social awareness) have significant positive impact on $\operatorname{EE}(\beta=.429, p=.000 ; \beta=.178, p=.006$, respectively).

Depending upon extant literature, some hypothesis are postulated:

H1: EI will significantly predict EE.

\section{Perceived Supervisor Support (PSS)}

PSS refers to "the degree to which its workers believe that their managers are concerned about the welfare of their workers, respect and generally accept their efforts "(Eisenberger et al., 2002). Kahn (1990) describes leading attitudes, demonstrating encouragement, stability, coherence, confidence and integrity that assist workers in employing themselves without any adverse implications to themselves, their position or their employment. Supervisor support aids employees for cultivating positive attitudes towards organization which in turn enhances their job involvement (Kaur \& Randhawa, 
2019), motivation and performance (Kalemci et al., 2019). Numerous studies (Rubel \& Kee, 2013) have investigated the impact of PSS on EE and reported that PSS has a major impact on EE.

Based on the foregoing ambivalent discussion, following hypothesis is framed:

H2: Perceived supervisor support will significantly predict EE.

\section{Work Life Balance (WLB)}

WLB can be described as "a satisfactory level of participation or 'fit' among the various roles of a person's life" (Hudson, 2005). This balance is very important for a person in order to ensure positive contribution to every sphere of his life. Bonoli (2005) revealed that supporting individuals to reconcile work and family obligations is a priority for organizations that seek welfare for its employees as it contributes to EE, which in turn contributes to higher productivity and lower employee turnover (Grawitch et al., 2006). The influence of WLB on EE has been studied by various authors (Alvi et al., 2014; Mansor et al., 2018; Larasati et al., 2019) and they found WLB has a significant positive influence on EE.

On account of the above argumentation, the following hypothesis is stipulated:

H3: WLB will significantly predict EE.

\section{Outcomes of EE}

There is a general belief that there is a link between EE as an individual level construct and organizational results (Harter et al., 2002). Thus, there is a need to explore the main outcomes of EE. For the purpose of this study, certain variables have been identified as key outcomes of EE.

\section{Organizational Citizenship Behaviour (OCB)}

Organ (1988) defines OCB as "unique conduct that, as a whole, encourages the effective workings of the organisation," that is optional, not expressly recognised in the formal reward system. Employees' meaningful engagement at work is a great asset for the organization as engaged employees often display OCB, stay motivated and less frequently quit the organization (Lockwood, 2007). Fay \& Sonnentag (2012 ) proposed an improvement in OCB implementation. Numerous studies (George \& Joseph, 2015; Abd-Allah, 2016; Handayani, 2018) have investigated the impact of EE on OCB and have reported that EE has major positive impact on OCB.

Depending over literature, hypothesis is drafted:

H4: EE has a significant positive impact on OCB.

\section{Organizational Commitment (OC)}

OC refers to "the strength of an individual's bond or identification with an organization". Maslach (2001) have found that the probability of workers engaged leaving the company is lower and that their level of OC is higher than that of disengaged employees. Various authors have examined the impact of EE on the OC and most found that E has a significant positive influence on ED. Similarly a research study was conducted with 138 junior executives employed in the Bangladeshi private sector finding that EE-size (employment and corporate engagement) is a positive influence on emotion $(\beta=.526, \beta=.432$, and $\mathrm{p}=.000)$.

Review of above mentioned research studies lead to drafting of following hypothesis: 
H5: EE has a significant positive impact on OC.

\section{Turnover Intentions (TI)}

TI refers to "conscious and deliberate willingness to leave the organization" (Tett \& Meyer, 1993). Alfes et al. (2013) have indicated that engaged employees tend to have less intention to leave the organization and are possibly to be with their existing employer, on the other hand employees who are disengaged have great intention to leave their organizations. A plethora of research studies (Shuck et al., 2011; Erdila \& Müceldili, 2014; Raza \& Nadeem, 2018) conducted on EE and TI suggested that EE possess important negative impact on TI. Also, Sandheya \& Sulphey (2019) conducted a study on 384 professionals of IT industry, India and concluded that EE explains 24 percent variance in TI. EE factor (dedication) has a mejor negative impact on TI $(\beta=-.608, \mathrm{p}=.000)$.

Based on the existing literature some hypothesis are proposed:

H6: EE has a significant negative impact on turnover intentions.

\section{Theoretical Model}

From literature review as well as the posited hypotheses, a theoretical model is proposed showing the key predictors and outcomes of EE in an integrated manner (see Figure 1). Although the past research has explored the individual relationships among the mentioned constructs, but there is a dearth of studies that have proposed the theoretical model in a holistic manner. Thus, the proposed model aims to fill the research gap by exploring the key predictors and outcomes of EE.

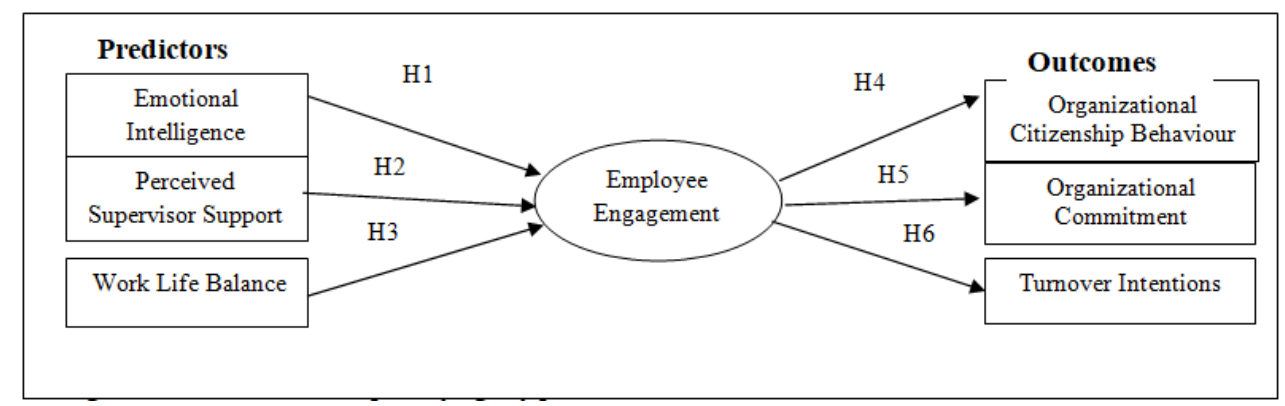

Figure 1: Theoretical Model Portraying Key Predictors and Outcomes of EE.

\section{CONCLUSIONS AND IMPLICATIONS}

In nutshell, the study attempted to illuminate the concept of EE and identified its key predictors and outcomes. The review of existing literature reveals that EE can be predicted by variables, including EI, PSS and WLB. Further, literature review also revealed that EE results in various organizational outcomes, such as OCB, OC and TI. Based on these identified relationships, the study proposed a theoretical model portraying the predictors and outcomes of EE. This research is intended to contribute to existing literature by strengthening existing perception of EE by defining the key predictors and outcomes of EE.

The growing relationship between employers and workers pushes HR professionals and their organizations to consider precisely what their employees are looking for and then to figure out how to reach those who can eventually make use of the EE. The theoretical model developed will act as a guide to HR professionals for making effective strategies during change initiatives. In addition, companies must increase their support for their workers to boost their job 
engagement, leading to better organizational outcomes. Rich et al.(2010) have indicated that organizations aiming to increase the EE must ensure that workers understand that they obtain organizational support to enhance job satisfaction and OCB, to minimize the rates of inefficient jobs, to improve organizational efficiency, etc.

\section{LIMITATIONS AND SUGGESTIONS FOR FUTURE RESEARCH}

The major limitation of this study is that the proposed model of predictors and outcomes of EE is theoretical one and based on literature review only. Therefore, it needs to be empirically tested and validated using tools and techniques like structural equation modeling (SEM). Future research can also focus on other variables like perceived organizational support (POS), job characteristics, working environment, etc. affecting EE. The effect of demographic variables, like gender, and income on EE can also be taken into consideration.

\section{REFERENCES}

1. Abd-Allah, O.M.Z. (2016). The relationship between organizational citizenship behavior and employee engagement in cement industry in Egypt. International Journal of Management and Commerce Innovations, 4(1), 362-376.

2. Alvi, K.A., Cheema, I.Q., \& Haneef, M. (2014). Does the relationship of work life balance and employee job engagement exist in banking sector of Pakistan? Science International, 26(4), 1761-1763.

3. Crabtree, S. (2005). Engagement keeps the doctor away. Gallup Management Journal, 13(January), 1-4.

4. Cropanzano, R., \& Mitchell, M.S. (2005). Social exchange theory: An interdisciplinary review. Journal of Management, 31(6), $874-900$.

5. Erdila, O., \& Müceldili, B. (2014). The effects of envy on job engagement and turnover intention. Procedia - Social and Behavioral Sciences, 150, $447-454$.

6. George, J.M. (2000). Emotions and leadership: The role of emotional intelligence. Human Relations, 53(8), 1027-1055.

7. Goleman, D. (2012). İş başında duygusal zekâ, çev. Handan Balkara, Varlık Yayınları, İstanbul.

8. Gong, Y., Wu, Y., Huang, Yan, X and Luo (2020). Psychological Empowerment and Work Engagement as Mediating Roles Between Trait Emotional Intelligence and Job Satisfaction. Frontiers in Psychology, 11, 1-7.

9. Handayani, N.P. (2018). Transformational leadership and employee engagement as a determinant of organizational citizenship behavior: Case study on youth non-profit organization. International Journal of Social Science and Humanity, 8(2), 59-64.

10. Hewitt, A. (2013). Trends in global employee engagement report highlights 2013. Retrieved from http://www.aon.com/attachments/human-capitalconsulting/2013_Trends_in_Global_Employee_Engagement_Highlights.pdf

11. Hudson (2005). The case of work life balance: Closing the gap between policy and practice. Hudson Global Resources (Aust) Pty Ltd. North America.

12. Kalemci, R.A., Tuzun, I.K., \& Canbolat, E.O. (2019). Employee deviant behavior: Role of culture and organizational relevant support. European Journal of Management and Business Economics, 28(2), 126-141.

13. Larasati, D.P., Hasanati, N., \& Istiqomah (2019). The effects of work-life balance towards employee engagement in millennial generation. Advances in Social Science, Education and Humanities Research, 304, 390-394.

14. Levitats, Z., Vigoda $\square$ Gadot, E., \& Vashdi, D. R. (2019). Engage Them through Emotions: Exploring the Role of Emotional Intelligence in Public Sector Engagement. 
15. Mansor, Z.D., Jaharudin, N.S., \& Nata, N.M. (2018). Employee engagement in public organizations in Malaysia. Proceeding of the $5^{\text {th }}$ International Conference on Management and Muamalah (pp. 258-272). Bangi, Malaysia.

16. Nanda, M., \& Randhawa, G. (2019). Emotional intelligence, employee well-being and employee behavior. Journal of Management Research, 19(3), 157-172.

17. Randhawa, G. \& Nanda, M. (2017). Emotional intelligence: Concept and correlates, Proceedings of International Conference on Research and Business Sustainability. (pp. 590-595). Noida, India.

18. Raza \& Nadeem (2018). Drivers of employee engagement and their impact on job satisfaction and turnover intentions. Journal of Managerial Sciences, 12(2), 171-191.

19. Rubel, M.R.B., \& Kee, D.M.H. (2013). Perceived support and employee performance: The mediating role of employee engagement. Life Science Journal, 10(4), 2557-2567.

20. Schaufeli, W.B., \& Bakker, B. (2004). Job demands, job resources, and their relationship with burnout and engagement: A multi sample study. Journal of Organizational Behavior, 25(3), 293-315.

21. Susi,S., \& Jawaharrani,K.(2011).Work life balance: The key driver of employee engagement.Asian Journal of Management Research,2(1),474-483

22. Susi,S., \& Jawaharrani,K.(2011).Work life balance: The key driver of employee engagement.Asian Journal of Management Research,2(1),474-483

23. Susi,S., \& Jawaharrani,K.(2011).Work life balance: The key driver of employee engagement.Asian Journal of Management Research,2(1),474-483

24. Susi,S., \& Jawaharrani,K.(2011).Work life balance: The key driver of employee engagement.Asian Journal of Management Research,2(1),474-483

25. Susi,S., \& Jawaharrani,K.(2011).Work life balance: The key driver of employee engagement.Asian Journal of Management Research,2(1),474-483

26. Susi,S., \& Jawaharrani,K.(2011).Work life balance: The key driver of employee engagement.Asian Journal of Management Research,2(1),474-483

27. Susi,S.,\& Jawaharrani,K.(2011).Work life balance: The key driver of employee engagement.Asian Journal of Management Research,2(1),474-483

28. Susi,S., \& Jawaharrani,K.(2011).Work life balance: The key driver of employee engagement.Asian Journal of Management Research,2(1),474-483

29. Susi,S., \& Jawaharrani,K.(2011).Work life balance: The key driver of employee engagement.Asian Journal of Management Research,2(1),474-483

30. Susi,S., \& Jawaharrani,K.(2011).Work life balance: The key driver of employee engagement.Asian Journal of Management Research,2(1),474-483

31. Susi,S., \& Jawaharrani,K.(2011).Work life balance: The key driver of employee engagement.Asian Journal of Management Research,2(1),474-483.

32. Susi,S., \& Jawaharrani,K.(2011).Work life balance: The key driver of employee engagement.Asian Journal of Management Research,2(1),474-483. 
33. Susi,S., \& Jawaharrani,K.(2011).Work life balance: The key driver of employee engagement.Asian Journal of Management Research,2(1),474-483.

34. Susi,S., \& Jawaharrani,K.(2011).Work life balance: The key driver of employee engagement.Asian Journal of Management Research,2(1),474-483.

35. Susi,S., \& Jawaharrani,K.(2011).Work life balance: The key driver of employee engagement.Asian Journal of Management Research,2(1),474-483.

36. Susi,S., \& Jawaharrani,K.(2011).Work life balance: The key driver of employee engagement.Asian Journal of Management Research,2(1),474-483.

37. Susi,S., \& Jawaharrani,K.(2011).Work life balance: The key driver of employee engagement.Asian Journal of Management Research,2(1),474-483.

38. Susi,S., \& Jawaharrani,K.(2011).Work life balance: The key driver of employee engagement.Asian Journal of Management Research,2(1),474-483.

39. Susi,S., \& Jawaharrani,K.(2011).Work life balance: The key driver of employee engagement.Asian Journal of Management Research,2(1),474-483.

40. Susi,S., \& Jawaharrani,K.(2011).Work life balance: The key driver of employee engagement.Asian Journal of Management Research,2(1),474-483.

41. Susi,S., \& Jawaharrani,K.(2011).Work life balance: The key driver of employee engagement.Asian Journal of Management Research,2(1),474-483.

42. Susi,S.,\& Jawaharrani,K.(2011).Work life balance: The key driver of employee engagement.Asian Journal of Management Research,2(1),474-483.

43. Susi,S., \& Jawaharrani,K.(2011).Work life balance: The key driver of employee engagement.Asian Journal of Management Research,2(1),474-483.

44. Susi,S., \& Jawaharrani,K.(2011).Work life balance: The key driver of employee engagement.Asian Journal of Management Research,2(1),474-483.

45. Susi,S., \& Jawaharrani,K.(2011).Work life balance: The key driver of employee engagement.Asian Journal of Management Research,2(1),474-483.

46. Susi,S., \& Jawaharrani,K.(2011).Work life balance: The key driver of employee engagement.Asian Journal of Management Research,2(1),474-483.

47. Susi,S., \& Jawaharrani,K.(2011).Work life balance: The key driver of employee engagement.Asian Journal of Management Research,2(1),474-483.

48. Susi,S., \& Jawaharrani,K.(2011).Work life balance: The key driver of employee engagement.Asian Journal of Management Research,2(1),474-483.

49. Susi,S., \& Jawaharrani,K.(2011).Work life balance: The key driver of employee engagement.Asian Journal of Management Research,2(1),474-483.

50. Susi,S., \& Jawaharrani,K.(2011).Work life balance: The key driver of employee engagement.Asian Journal of Management Research,2(1),474-483. 
51. Susi,S., \& Jawaharrani,K.(2011).Work life balance: The key driver of employee engagement.Asian Journal of Management Research,2(1),474-483.

52. Susi,S., \& Jawaharrani,K.(2011).Work life balance: The key driver of employee engagement.Asian Journal of Management Research,2(1),474-483.

53. Susi,S., \& Jawaharrani,K.(2011).Work life balance: The key driver of employee engagement.Asian Journal of Management Research,2(1),474-483. 